\title{
Application of Goods and Services Tax (GST) in India (With Reference to Perception of Consumer in Chennai City)
}

\author{
R.M. Duraiarasan, M. Ramila
}

\begin{abstract}
The main objective of taxation is to raise revenue for the State. It is an effective tool to achieve higher level of economic development. In India, presentation of Value Added Tax (VAT) at the Central and the State level has been viewed as a noteworthy advance of roundabout duty changes. If the VAT is a major improvement at the national level and the business charge framework at the State level, at that point the Goods and Services charge (GST) is an extra significant towards an indirect tax reforms for India. Under the GST regime, there is no difference is made between goods and services for levying of tax. It draw in a similar pace of assessment. This investigation, unmistakably display the mindfulness level of buyers towards GST and its utilization and advantage.
\end{abstract}

Keywords : VAT, Economic Development, GST regime, Awareness, Usage and Benefit.

\section{INTRODUCTION}

$\mathrm{T}$ he Government of India, implemented GST on 1st July 2017 to overcome the problems of existing tax system like multiplicity of central and state indirect taxes, absence of comprehensive input tax system, cascading of tax by levy of VAT on Excise duty, Service Tax. Lack of integration between Goods and Services Tax narrow tax base, Multiple Registration, different points of taxation, lack of uniformity and dilemma between Goods and Services, the government of India realised the need to adopt the principle of the nation one duty to supplant all roundabout expenses required on Goods and Services by State and Central. It is a memorable assessment change on aberrant duties since autonomy. The primary motivation behind acquaintance of GST with bring into overlay a uniform structure. GST (Goods and Services Tax) is otherwise called Harmonized Sales Tax or VAT or General Sales Tax. GST is a proposed duty on worth expansion of provisions of merchandise and enterprises. The principle goals of the proposed assessment is to diminish the falling impact without breaking the chain of credit. GST in India have tax collection control both by the Central and the State to require charge on the Goods and Services. Just about

Revised Manuscript Received on December 05, 2019.

* Correspondence Author

Dr. R.M. Duraiarasan*, Assistant Professor, Department of Commerce, Patrician College of Arts \& Science, Adyar, Chennai, India. Email: rm.mani08@gmail.com

Dr. M. Ramila, Assistant Professor, PG and Research Department of Commerce, Guru Nanak College, Velacherry, Chennai, India. Email Id: ramilagnc2017@gmail.com
150 nations have presented GST in some structure or other. Nations like Singapore and New Zealand have presented at a solitary rate, while Indonesia has five positive rate, a zero rate and 30 classifications of exclusion and in China, GST applies just to the merchandise and of fixes, substitution and handling.

\section{A. History of GST in India}

The introduction of One GST to promote a common market in India which has been attempted since the union budget 2006-2007. A bill was amended in order to introduce GST in 2011; but due to lack of unity and harmony of the political scenario, the bill could not be taxed. During 2011, the bill was introduced with amendments act as to;

- Petroleum and Alcohol

- Introduction of the additional $1 \%$ levy on Inter-State supplies

- With a Guarantee that States would be reimbursed for any losses due to implementation of GST.

Later in December 2014, the Government tabled introduced another bill with necessary amendments on the provisions of the constitution. Finally, the GST Act was promulgated effective from 1st July 2017 throughout India, taking into consideration the various demands.

\section{B. GST - Worldwide}

France was the primary nation to present GST in 1954. All inclusive, there are 150 nations are in the game of GST consistency. Be that as it may, Brazil and Canada pursue a double framework. GST paces of couple of nations are given beneath: (T.S. Reddy and Y. Hari Prasad Reddy)

\begin{tabular}{|c|c|}
\hline Country & Rates of GST \\
\hline Australia & $10 \%$ \\
\hline France & $19.6 \%$ \\
\hline Canada & $5 \%$ \\
\hline Germany & $19 \%$ \\
\hline Japan & $5 \%$ \\
\hline Singapore & $7 \%$ \\
\hline New Zealand & $15 \%$ \\
\hline
\end{tabular}

\section{Administration of GST}

In India, there are two components of GST to be specific, Center GST (CGST) and State GST (SGST). Both Center 
and State GST will be gathered from Goods and Services at the same time.

Focus would require and gather Central Goods and Services Tax (CGST) and States would exact and gather the State Goods and Services Tax (SGST) on all exchange inside a State.(T.S. Reddy and Y. Hari Prasad Reddy)

\section{Existing Indirect Tax Structure}

CENTRAL: Central Excise Duty, Service Tax, Additional Excise Duty, Additional Customs Duty and Special Additional Duty of customs.

STATE: Entertainment Tax, Central Sales Tax, State Value Added tax or Sales Tax, Entry tax and Octroi, Purchase Tax, Luxury Tax and Taxes on Lottery and Betting and Gambling.

INTEGRATION OF INDIRECT TAXES WITH GST: VAT/Sales Tax, Entertainment Tax, Luxury Tax, Taxes on Lottery, Betting and Gambling, State Cesses and Surcharges. The above taxes replaced with the introduction of GST with CGST and SGST. (T.S. Reddy and Y. Hari Prasad Reddy)

\section{E. Exempted Goods and Services Under GST}

Goods exempt from GST: Animals, Meat of animals, fish seeds and prawn, fresh milk and pasteurized milk, chena or pancer natural honey, live trees, vegetables, bananas, all goods of seed quality, fresh ginger, wheat and meslin, plants and parts of plants, jiggery, puffed rice, papad, prasadam (supplied in religious places), water, non-alcoholic toddy, tender coconut water, aquatic feed, salt, electrical energy, human blood, contraceptives, manure, kajal, municipal water, fire wood, wood charcoal, stamp papers, postal items, rupee notes, cheque, printed books, children picture books, silk worm, earthen pot, agricultural impliments, hand loom, space craft, hearing aids, puja samagri namely rudraksha, tulsimala etc., and lottery. (T.S. Reddy and Y. Hari Prasad Reddy)

Services exempt from GST: Services rendered by charitable trust, transfer of a going concern, services to Government, services by the Central Government, State Government, Union Territory or local authority, services rendered by Government or a local authority to a business entity exempt if turnover does not exceed Rs. 20 lakhs or Rs. 10 lakhs in special category states are exempt, services provided by Government or a local authority to another Government or a local authority, services rendered by Government or union territory or local authority where the consideration does not exceed Rs. 5000 are exempt and original works pertaining to the housing for all (urban) mission or pradahan mantra awasyojana are exempt. (T.S. Reddy and Y. Hari Prasad Reddy)

\section{REVIEW OF LITERATURE}

Vineet Chouhan, Pushpkant Shakdwipee and Shagufta Khan (2017), have explored in their study on the awareness about implementation of GST: A survey of small business owners of Rajasthan. They have found that there is a lack of awareness amongst the small business owners regarding the GST and its rule. Moreover, they also found that the small business owners have refused to pay GST due to the problem of submitting report to authority. They also felt that the GST model was very technically complicated for them. The authors have concluded that the awareness towards the implementation of GST was relatively low and moderate and most of the respondents were also not willing to support and accept the implementation of GST.

Jayram (2017), conducted a study on the "Effect of GST on GDP growth", evidences from Asia Pacific Region especially on Jordan, Singapore, New Zealand, Australia, Malaysia and Papua New Guinea. The study has show that the GDP growth rate, before and after implementation of GST in Asia Pacific region clearly exhibit a different picture. The author has identified that only Jordan was successful in increasing the GDP growth rate higher in the ten years average before implementation of GST. Other countries were also successful in increasing GDP rate in initial period but later on lost their momentum. The author has also found that there was a mixed trend in GDP growth rate pattern after implementation of GST and concluded that, the GST implementation won't be helpful in recording a higher growth rate.

Ramesh R Kulkarni (2016), has analyzed the mindfulness and readiness about merchandise and ventures charge among the retail organizations in India particularly on Hubli-Dharwad City. The examination has delighted that dominant part of the respondents know about the new expense structure however the retail business respondents are not clear with regards to the advantage of GST, for example, straightforwardness in duty, one point installment, decrease in assessment, decrease in falling impact and simplicity in exercise. The examination has likewise referenced that, solitary $30 \%$ of retailers know about GST and arranged to make good on government obligation on the web and larger part of the retailers are needy upon the expense experts' recommendation about the installment of duty.Therefore, the author has concluded that the suitable campaigns awareness be conducted about GST and its structure.

\section{STATEMENT OF PROBLEM}

India expects to receive a double GST which will be forced simultaneously by the focal and states. The proposed double structure GST, looks to disentangle the complex roundabout duty framework in India and make a typical national market by cutting down monetary hindrances between the states. GST is another assessment framework which is stuffing to an effective backhanded expense system. It ends up basic for customers to keep themselves refreshed with this new assessment framework in the nation's duty scene. In this manner the present examination completed has made an endeavor to explore the recognitions towards GST among the buyers has been done.

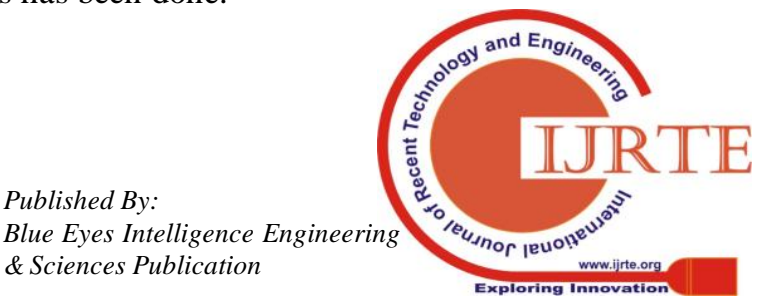




\section{NEED FOR THE STUDY}

This research will look at the effect of GST after its execution in India and it will toss light in the hole between present aberrant assessments and GST, and furthermore the investigation will uncover the advantages and difficulties of GST after usage.

\section{OBJECTIVE}

The objectives of the study are as follows:

1) To study the level of awareness of Goods and Services Tax (GST) among the consumer

2) To analyse the usage and benefit obtained by adopting Goods and Services Tax (GST)

\section{RESEARCH METHODOLOGY}

Primary data is considered for undertaking the study. The required primary data have been collected through structured questionnaire administrated to the respondent consumers of goods and services in Chennai city to elicit their responses. The sample size for this study is 101 . The study is based on convenience sampling method to collect the data.

\section{EMPIRICAL RESULTS AND DISCUSSION}

Objective 1: To study the level of awareness of Goods and Services Tax (GST) among the consumer.

Table - 1: Demographic Profile of the Respondents

\begin{tabular}{|c|c|c|}
\hline Variables & Frequency & Percentage \\
\hline Age & & \\
\hline $20-25$ & 28 & 27.7 \\
$26-30$ & 47 & 46.5 \\
$31-40$ & 22 & 21.8 \\
$41-45$ & 2 & 2.0 \\
Above 45 & 2 & 2.0 \\
\hline Gender & & \\
\hline Male & 63 & 62.4 \\
Female & 38 & 37.6 \\
\hline Marital Status & & \\
\hline Married & 36 & 35.6 \\
Unmarried & 65 & 64.4 \\
\hline Educational Qualification & & \\
\hline UG & 27 & 2.0 \\
PG & 38.7 \\
M.Phil & & 37.6 \\
Ph.D. & & \\
\hline Monthly Income & & \\
\hline & & \\
\hline
\end{tabular}

\begin{tabular}{|l|c|c|}
\hline Less than 15000 & 37 & 36.6 \\
$15001-25000$ & 19 & 18.8 \\
$25001-35000$ & 18 & 17.8 \\
above 35000 & 27 & 26.7 \\
\hline Occupation & & \\
\hline Student & 16 & 15.8 \\
Salaried & 48 & 47.5 \\
Self Employed & 2 & 2.0 \\
Professional & 35 & 34.7 \\
\hline Source of Information about GST & 54 & \\
\hline Newspapers & 0 & 0 \\
Magazines & 32 & 31.7 \\
Official websites & 15 & 14.9 \\
Others & & \\
\hline How frequently you update the GST & & \\
information? & 25 & 24.8 \\
\hline Hourly & 52 & 51.5 \\
Daily & 23.8 \\
Weekly & & \\
Monthly & & \\
\hline
\end{tabular}

The above table shows, demographic profile of respondents. $46.5 \%$ are found in the age group of 26-30 years. It can be deduced that male constitute $62.4 \%$ and $37.6 \%$ are female respondents. Further, the table has indicated that $64.4 \%$ of the respondents are unmarried. The table also shows that $37.6 \%$ of sample are Ph.D. degree holders. It also exhibits that $36.6 \%$ of respondents monthly income is less than Rs. 15,000/-. Further, it is noted that, $47.5 \%$ of are salaried category. $53.5 \%$ of respondents are aware of GST through newspapers and $51.5 \%$ possess update the current information about GST.

Objective 2: To analyse the usage and benefit obtained by adopting Goods and Services Tax (GST)

\section{Factor Analysis on Pros and Cons of GST}

In this part of analysis, the researcher attempt to group the variables which is stated in the questionnaire into factors. The results of analysis are presented below:

\section{Reliability Statistics on Usage and Benefit of GST}

Cronbach's alpha is a measure of internal consistency, which is closely related to a set of variables as a group. It is a measure of scale of reliability. It provides an evidence that the scale in question is uni-dimensional. Besides, Cronbach's alpha also satisfies the function of the number of test items and the average inter-correlation among the variables.

Table - 2: Reliability Statistics on Usage and Benefit

\begin{tabular}{|c|c|c|}
\hline Perception on GST & Cronbach's Alpha & No. of Variables \\
\hline Usage and Benefit & .719 & 19 \\
\hline
\end{tabular}

Source: Computed data 
The above table shows that, Cronbach-Alpha test was utilized to decide the level of consistency among the numerous estimations of each factor. It quantifies the between thing unwavering quality of scale produced from various things. The reactions displayed Cronbach-Alpha estimation of 0.719 for things identified with utilization and advantage of the GST by respondents. The alpha qualities are factually huge to guarantee a smooth typical circulation and to defend the example measurements for the portrayal of populace parameters.

Table - 3: KMO and Bartlett's Test

\begin{tabular}{|c|c|c|}
\hline \multicolumn{2}{|c|}{ Kaiser-Meyer-Olkin Measure of Sampling Adequacy. } & .719 \\
\hline \multirow{3}{*}{ Bartlett's Test of Sphericity } & Approx. Chi-Square & 1240.509 \\
\cline { 2 - 3 } & Df & 171 \\
\cline { 2 - 3 } & Sig. & .000 \\
\hline
\end{tabular}

It is understood from the Table that KMO measure of sampling adequacy is 0.719 and Bartlett's test of Sphericity is 1240.509 at significance of $\mathrm{P}=0.000$. These values are statistically significant at 5 percent level. It shows that the sample size is adequate for the data reduction process, with considerable variance of the variable presented in the communality Table.

Table - 4: Total Variance

\begin{tabular}{|c|c|c|c|c|c|c|}
\hline \multirow{2}{*}{ Component } & \multicolumn{3}{|c|}{ Initial Eigenvalues } & \multicolumn{3}{c|}{$\begin{array}{c}\text { Rotation Sums of Squared } \\
\text { Loadings }\end{array}$} \\
\cline { 2 - 7 } & Total & $\begin{array}{c}\% \text { of } \\
\text { Variance }\end{array}$ & $\begin{array}{c}\text { Cumulative } \\
\%\end{array}$ & Total & $\begin{array}{c}\% \text { of } \\
\text { Variance }\end{array}$ & $\begin{array}{c}\text { Cumulative } \\
\%\end{array}$ \\
\hline 1 & 7.030 & 37.000 & 37.000 & 3.951 & 20.795 & 20.795 \\
\hline 2 & 2.168 & 11.411 & 48.411 & 3.837 & 20.195 & 40.990 \\
\hline 3 & 1.795 & 9.450 & 57.861 & 2.265 & 11.921 & 52.911 \\
\hline 4 & 1.462 & 7.696 & 65.557 & 1.987 & 10.460 & 63.371 \\
\hline 5 & 1.173 & 6.173 & 71.730 & 1.588 & 8.359 & 71.730 \\
\hline
\end{tabular}

From the above table, displays that 19 factors are diminished to five dominating elements. The absolute combined estimation of the fluctuation is 71.730 percent are measurably huge at 5 percent level. It is likewise found out that the five factors separately have the changes 20.795 percent, 20.195 percent, 11.921 percent, 10.460 percent, and 8.359 percent. This prompts the variable loadings for every factor of the utilization and advantages of the GST.

Table - 5: Rotated Component Factor Loadings

\begin{tabular}{|c|c|}
\hline \multicolumn{1}{|c|}{ Dimensions and Items } & $\begin{array}{c}\text { Factor } \\
\text { Loadings }\end{array}$ \\
\hline Pecuniary & .802 \\
\hline GST improves the economic conditions of the people & .774 \\
\hline GST reduce the corruption in India & .718 \\
\hline GST improve the GDP growth in India & .702 \\
\hline $\begin{array}{l}\text { GST increment the aggressiveness of Indian products and } \\
\text { enterprises in the global market and offer lift to Indian } \\
\text { fares }\end{array}$ & .520 \\
\hline $\begin{array}{l}\text { Government produce effective Information Technology } \\
\text { (IT) Infrastructure through GST }\end{array}$ & \\
\hline Annihilate &
\end{tabular}

The first factor consists of five variables namely GST improves the economic conditions of the people, GST reduce the corruption in India, GST improve the GDP growth in India, GST increment the aggressiveness of Indian products and enterprises in the global market and offer lift to Indian fares and Government produce effective Information Technology (IT) Infrastructure through GST. Therefore, these variables from usage and benefit on GST are suitably named as Pecuniary.

The second factor consists of seven variables: Uniformity of expense rates and structures, It eliminate the multiplicity of tax system, it reduces transactions costs due to single registration and compliance for both CGST and SGST, It promotes for Aggregate tax rate reduced, GST enhance the trust on tax collection, GST increases the financial sustainability and GST prompts higher measure of income to both the State and Central. Therefore, these variables from usage and benefit on GST are suitably named as Annihilate.

The third factor consists of two variables GST will build charge accumulations because of wide inclusion of Goods and Service and GST PAN-connected framework is encourage information trade and citizen consistence. Therefore, these variables from usage and benefit on GST are suitably named as Augmentation.

The fourth factor consists of three variables namely it is applicable to all transactions of goods and services except exempted Petroleum and Alcohol, GST eliminates the

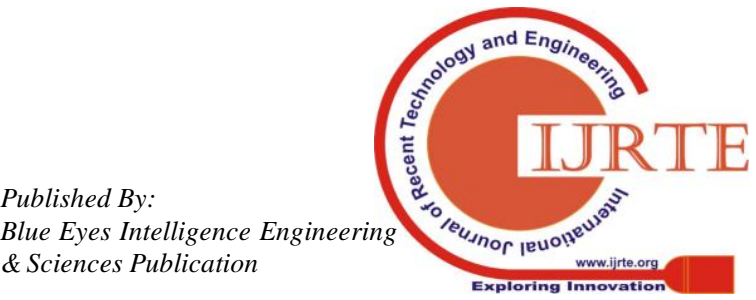


cascading effect of taxes and GST is a single enrollment and consistence will do the trick for both CGST and SGST. Therefore, these variables from usage and benefit on GST suitably named as Freed.

The fifth factor consists of two variables as Tax payer as to submit periodical return in like way course of action to both CGST and SGST masterand GST indicates the level of Tax system used in the economy. Therefore, these variables from usage and benefit on GST suitably named as Glassy.

Table - 6: Chi - Square results

\begin{tabular}{|c|c|c|c|}
\hline Hypothesis & $\begin{array}{c}\text { Chi-square } \\
\text { Value }\end{array}$ & $\begin{array}{c}\text { Asymp.Sig. } \\
\text { (2-sided) }\end{array}$ & Result \\
\hline Age & $240.369 \mathrm{a}$ & 0.000 & Significant \\
\hline Gender & $65.934 \mathrm{a}$ & 0.000 & Significant \\
\hline Marital Status & $62.592 \mathrm{a}$ & 0.000 & Significant \\
\hline $\begin{array}{c}\text { Educational } \\
\text { Qualification }\end{array}$ & $171.331 \mathrm{a}$ & 0.000 & Significant \\
\hline $\begin{array}{c}\text { Monthly } \\
\text { Income (Rs.) }\end{array}$ & $179.292 \mathrm{a}$ & 0.000 & Significant \\
\hline Occupation & $169.758 \mathrm{a}$ & 0.000 & Significant \\
\hline
\end{tabular}

From the above table, it is evidenced that the chi-square value of Age 240.369a (0.000), Gender65.934a (0.000), Marital Status 62.592a (0.000), Educational Qualification 171.331a (0.000), Monthly Income 179.292a (0.000), Occupation 169.758a (0.000) of the respondents are significant at the level of $5 \%$ with the usage and benefits of GST. The results show that there is a significant relationship between usage and benefits of GST and age, gender, marital status, educational qualification, monthly income, occupation.

\section{FINDING}

\section{Demographic profile of respondents}

The study has reveled that the overall age distribution indicates that 46.5 percent of respondents fall in the age group of 26-30 years. Further, it is found that the 62.4 percent of the respondents are male. The study also shows that proportion of unmarried respondents are more than married respondents. It is also found that the 37.6 percent of the respondents educational qualification is $\mathrm{Ph} . \mathrm{D}$. It is observed that 36.6 percent of the respondents earn income less than 15,000 per month and 47.5 percent of them are salaried. Furthermore, it is found that 53.5 percent possesses the knowledge on the information about GST through newspapers. In addition that, it is found that 51.5 percent of respondents are weekly update the current information about GST.

Usage and benefit obtained by adopting Goods and Services Tax (GST)

\section{Reliability Test}

The Cronbach alpha coefficient value of variables relating to usage and benefits obtained by adopting GST is 0.719. The alpha qualities are measurably huge and guarantee a smooth ordinary appropriation and this legitimizes the example measurements for the portrayal of populace parameters. The specialist endeavored to recognize the elements in charge of utilization and advantage acquired by embracing Goods and Services Tax (GST) with upwards of 19 factors statements in the poll, information decrease was done through the use of factor examination by head segment technique. The KMO proportion of the inspecting sufficiency was observed to be 0.719 and Chi-square estimation of $1240.509, \mathrm{P}=0.000$ and these are measurably huge at 5 percent level. Moreover, it is discovered that 19 factors range from 20.8 percent to 71.7 percent, which is over the seat sign of 20 percent. In this manner, the information decrease is significant.

\section{Factor analysis}

Through the factor analysis all the 19 variables related to usage and benefit obtained by adopting GST were segmented into five predominant factors viz., pecuniary, annihilate, Augmentation, freed and glassy.

\section{Chi-square analysis}

The chi-square analysis, intends to associate the perception of respondents towards the usage and benefit obtained by adopting GST with demographic variables. It is found that there is an association between usage and benefit obtained by adopting GST among the different age group, gender, marital status, educational qualification, monthly income and occupation.

\section{CONCLUSION}

India's greatest assessment change has turned into a reality. A double Goods and Services charge (GST) has been presented and supplanted the complex various aberrant expense structure. The examination introduced above demonstrates that India's greatest assessment change has turned into a reality. A double Goods and Services charge (GST) has been presented and supplanted the complex numerous roundabout expense structure. The present study shows that respondents are more aware about GST. Further, that awareness about GST information is mainly through newspapers. GST is the biggest tax reforms for every country. In India, GST is introduced in recent scenario only, thus the awareness level about GST and its usage and benefit will be comparatively low. Thus the Government has to initiate necessary steps to improve the awareness among the public through education, conduct of proper training causes, continuous seminars and workshops about the GST its usage and benefit. 


\section{REFERENCES}

1. VineetChouhan, PushpkantShakdwipee and Shagufta Khan (2017), "Measuring Awareness about implementation of GST: A survey of small business owners of Rajasthan", Pacific Business Review International, Vol: 9 Issue No: 8, Pp. No:116-125.

2. Jayram (2017), "An empirical study on the effect of GST on GDP growth, evidence from Asia Pacific Region", International Journal of Economic Research, ISSN No: 0972-9380, Volume No: 14, Issue No:4, Pp: 31-41

3. Ramesh R Kulkarni (2016), "Awareness and preparedness about Goods and Services tax among the retail businesses in India - An Empirical study of Hubali-Dharwad City", International Journal of Informative and Futuristic Research, ISSN No: 2347-1697,Vol: 4, Issue No: 4 Pp. 5771-5778

4. T.S. Reddy and Y. Hari Prasad Reddy, "Business Taxation (Goods and Services Tax - GST)", ISBN No: 978-93-86398-39-0, Pg. No: 2.2, 2.8 , $2.13,4.1-4.4$

\section{AUTHORS PROFILE}

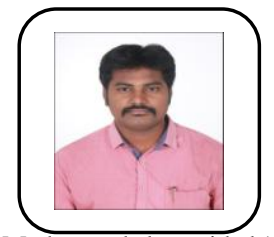

Dr. R.M. Duraiarasan, M.Com., M.Phil., NET. SET., Ph.D. is Assistant Professor in Department of Commerce in Patrician College of Arts and Science, Adyar, Chennai. His core area of research interest is Human Resource Management and Accounts. He has 4 years UG and PG teaching experience. He is M.Phil. Research Supervisor for University of Madras and also guided 12 M.Com research project. He has published 8 articles in UGC approved Journal, National and International Journals with high impact factor. Further, he has presented and participated in National and International Conferences, Seminars and has attended many workshops. He is also reviewed marketing, financial management and principles of management books of Charulatha Publication, 2019. He is organized National and International Conference in College and also on behalf of India, he participated at International level 'Common Wealth Youth Program which was held at Delhi. He is also a recipient of University Research Fellowship (URF) in University of Madras. He is also Board of Examiner for University of Madras, UG External Examiner.

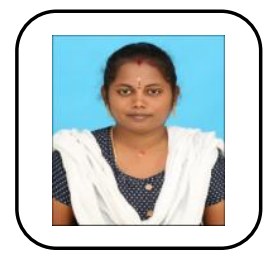

Dr. M. RAMILA, M.Com., M.Phil., NET (JRF)., Ph.D., is Assistant Professor in PG and Research Department of Commerce, Guru Nanak College (Autonomous), Chennai. She has 4 years of UG and PG teaching experience. Her core area of research interest is Banking, Finance and Marketing. She has published 9 articles in UGC approved journal, National and International Journals with high impact factor. Further, she has presented and participated in National and International Conference, Seminars and also attended many workshops in other State. She is Board of Examiner for University of Madras, UG External Examiner. She is also reviewed marketing, financial management and principles of management books of Charulatha Publication, 2019. 